\title{
1 \\ Fluid Boundaries and Ambiguous Identities
}

At Suva you pass from Polynesia into Melanesia and into the Australasian sphere of influence. The Fijis are ruled from London, but one begins to be aware of Sydney and Wellington west and south. ${ }^{1}$

Australia's place in the region has changed over time. In the 1880 s, it was part of a collection of British colonies referred to generically as the 'antipodes' or 'Australasia'. In 1912, an Australian shipping company portrayed the country as 'the greatest of the South Sea Islands, the centre around which the smaller constellations are scattered'. ${ }^{2}$ By 1942, an Australian journalist described the Pacific Islands in the quotation above in terms of a collection of 'spheres of influence'. This latter description may more accurately conceptualise the fluid political and cultural boundaries within the Pacific_-boundaries with spheres of influence radiating from specific Islands and Island groups, from villages and towns, from trading posts and missionary stations, and from traditional political centres and colonial administrative nodes. These spheres of influence shaped the routes and experiences of the travellers who crossed them, and transnationalism was tied to the specific political identification with these Islands. In this ambiguous and contested geographical region, travel writing can indicate to us the changing meanings and uses of terms. This is ultimately necessary for understanding how travellers conceived the world beyond their own, a world to which they compared and defined themselves.

1 Paul McGuire, Westward the Course: The New World of Oceania (Melbourne: Oxford University Press, 1942), 59.

2 Burns, Philp \& Company, Limited, Picturesque Travel, no. 2 (1912), 54. 
Most travellers who embarked on their voyages to the Pacific Islands used terms such as 'South Seas', 'South Pacific', 'Polynesia', 'Melanesia' and 'Australasia' to describe their routes and destinations. These general terms were the products of literary fiction and scientific classifications, variously appropriated and misappropriated by travellers for different purposes and contexts. The preference for these generalised descriptors instead of specific Island names and cultures reflects the ambiguous nature of European geographical knowledge of the Pacific Islands, as well as the dominance of imagined ideals and stereotypes. These terms may have been preferred due to the constantly shifting boundaries of colonial influence over time, as well as the popular belief in the immutability of race. A similar issue of terminology can be applied to the Australian continent and its inhabitants; although the official history of the nation-state began in 1901, naming conventions and boundaries continued to shift in the twentieth century. How did Australians identify and locate the South Seas, and how did they situate themselves within the region? This chapter will first consider colonial Australia's own oceanic connections and internal differences, and then it will explore how Australians demarcated the South Seas region. It will trace how an Australian literary culture and publishing industry emerged, as well as analyse the role that it played in shaping an Australian perspective of the Pacific that was distinct from those of other nations.

\section{Oceanic Imaginary: A Land Girt by Sea}

The immense size and geographical diversity of the Australian continent have at times obscured its Oceanic characteristics: it is an island bordering the Pacific Ocean, with more than 85 per cent of its population currently living within 50 kilometres of the coastline. Before it was claimed as a British colony in 1788, there was an estimated Indigenous population of 750,000 people who spoke over 700 languages and dialects. ${ }^{3}$ Termed 'Aboriginals' by the British settler colonials, they were considered culturally and racially distinct from Pacific Islanders. Comparisons between the two were rare in travel writing, despite the fact that Aboriginal Australians were connected beyond continental boundaries, including the islands between Australia and New Guinea, which is why they are presently referred to as

3 'Aboriginal and Torres Strait Islander Population', Australian Bureau of Statistics, last modified 3 June 2010, www.abs.gov.au/ausstats/abs@.nsf/0/68AE74ED632E17A6CA2573D200110075?open document. 
Aboriginal and Torres Strait Islanders. ${ }^{4}$ Even the terms 'Australian' and 'native' have assumed multiple meanings over time, being variously used to refer to Aboriginal Australians or European colonists. ${ }^{5}$ The European inhabitants of the country before the federation of the colonies in 1901 are more accurately referenced as colonial Australians (although national identity after this time remained contested and ambiguous). Unless referring to a specific historical period, the term 'Australia' in this book is used to generically refer to the literature or people produced by the continent during the late nineteenth and twentieth centuries.

Like Frances Steel's history of New Zealand shipping in the Pacific, Australian history can benefit from a more 'multi sited (-sighted) gaze' that looks to the sea as much as it does to the land. ${ }^{6}$ Colonial Australians have historically shared a strong connection to the Pacific Islands and the maritime world in general, displaying pride in the British traditions of seamanship and navigation. For example, the initial composition for 'Advance Australia Fair' in 1879 included the lyrics 'Britannia rules the wave' and revered 'gallant' Captain James Cook as a popular hero who was emblematic of 'British courage' and naval skill. ${ }^{7}$ Sydney, in particular, was a port city built on sea trade and harbour life- 'waterborne and waterbound', according to Grace Karskens. Rather than being a barrier, the ocean provided a connection to England and to the rest of the world. ${ }^{8}$ Sydney Harbour and its visiting seamen inspired popular writers such as Joseph Conrad, Henry Lawson and Kenneth Slessor. Ian Hoskins noted how the regular arrival of the HMS Powerful (the flagship of the British navy's Australia station), the visit of the American Great White Fleet in 1908 and the reception of Australia's first naval fleet in 1913 all attracted wide attention. ${ }^{9}$ Popular interest in sailing and navigation resurged in the 1920s and 1930s, which is evident in several accounts of travel on private sailing vessels that were inspired by Jack London's The Cruise of the Snark (1911).

\footnotetext{
4 In this book, reference to Aboriginal Australians does not include Torres Strait Islanders unless specifically mentioned.

5 Denoon, 'Re-Membering Australasia', 296.

6 Steel, Oceania under Steam, 9.

7 Peter Dodds McCormick, Advance Australia Fair (Sydney: Reading \& Co, 1879).

8 Grace Karskens, The Colony: A History of Early Sydney (Crows Nest: Allen \& Unwin, 2010), $161,166$.

9 Ian Hoskins, Sydney Harbour: A History (Sydney: UNSW Press, 2011), 232.
} 
Australia's oceanic origins were constrained by a turn to the interior, particularly from the 1820s onwards. A national character was beginning to form on the Australian colonial frontier, yet the ocean remained a vital link and an important part of the lifestyle and culture of many people. Early trading ventures between the Australian continent and the Pacific cemented this bond-so important was the Pacific in colonial Australia that John Young described it as 'Australia's Pacific Frontier'. ${ }^{10}$ The Australian colonial gaze was torn between the sea and the land, with both domains being perceived as pathways for returning 'home', as escape destinations, as opportunities for social betterment, as spaces of danger and threat or as spaces to be explored, known, owned and colonised.

For the first colonial settlers in Australia, knowledge of the Pacific Islands was influenced by the popular imagination of Europe. Few of the settlers travelled through the Pacific Islands before the 1880s, and the Pacific Islands were frequently identified as the 'South Seas', a term coined by Spanish explorer Vasco Núnez de Balboa in 1513. The term was derived from the classical Greek myth of an antipodean southern landmass that counterbalanced the north. ${ }^{11}$ Fictional tales of adventure incorporated the accounts of returning travellers and continued to place protagonists on an unspecified 'cannibal', 'savage', 'coral', 'tropical' or 'treasure' island within the South Seas, cementing the Pacific Islands as a generic and exotic backdrop upon which European actors played. These ambiguous descriptors persisted in Australian travel accounts and were more prevalent than terms such as 'Pacific' or 'Oceania'. The Islands continued to serve as ideal settings for boyhood adventure tales in the late nineteenth century, which were popular, influential and valued in Australia for their educational content and entertainment. ${ }^{12}$

10 Young, Australia's Pacific Frontier. See also Bill Gammage, 'Early Boundaries of New South Wales', Australian Historical Studies 19, no. 77 (1981): 524-31, doi.org/10.1080/10314618108595657; DR Hainsworth, 'Exploiting the Pacific Frontier: The New South Wales Sealing Industry 1800-1821', Journal of Pacific History 2, no. 1 (1967): 59-75, doi.org/10.1080/00223346708572102; John Young, Adventurous Spirits: Australian Migrant Society in Pre-Cession Fiji (St Lucia: University of Queensland Press, 1984).

11 Bronwen Douglas, Science, Voyages, and Encounters in Oceania, 1511-1850 (Basingstoke, UK: Palgrave Macmillan, 2014), 4.

12 Henry Maurice Saxby, A History of Australian Children's Literature 1841-1941 (Sydney: Wentworth Books, 1969), 24; Bill Pearson, Rifled Sanctuaries: Some Views of the Pacific Islands in Western Literature to 1900 (Auckland: Auckland University Press, 1984), 58. 
Another popular regional term that encompassed the Australian colonies and the South Seas was 'Australasia'. First coined in 1756 by the French philosopher Charles de Brosses as one of his three divisions of 'Terra Australis', the term initially categorised the lands south of Asia. It was then defined in 1890 by the Victorian parliament as including the Australian mainland, New Zealand, Tasmania, Fiji 'and any other British colonies or possessions in Australasia now existing or hereafter to be created'. ${ }^{13}$ Not only did Australasia express a collective British identity of shared 'migration ... similar social structures, economic enterprises and political institutions', it also described a network in which colonies supported, competed and compared themselves to one another. ${ }^{14}$

Significant diversity was found within these Australasian colonies, including different relationships with, and attitudes to, the Pacific Islands. Roger Thompson's history highlights the discord over foreign policy and trade in the Pacific between the eastern Australian colonies and the British Colonial Office, as well as the role of particular businesses, religious groups and individuals who lobbied the government when public interest waned. ${ }^{15}$ Of all the Australian colonies, those on the eastern seaboard were more closely connected to the Pacific Islands. New South Wales benefited from Sydney's strategic location at the centre of Pacific trade and advocated a free-trade ideology, displaying less interest in annexation and protectionist policies than the other Australian colonies. Victoria was the seat of the national government from 1901 to 1927, with its Presbyterian Church being a dominant lobbyist for the annexation of the New Hebrides (where their missions had vested interests). This call for annexation was not heeded as strongly by the Catholic population of Sydney. Queensland's close proximity to the Pacific Islands entailed a closer exchange of people and goods than other colonies. The demand for cheap labour to maintain the colony's sugar plantations drove the Queensland labour trade from 1869 to 1906 . Variations between rural and urban communities were also present within these colonies, not to mention that many travellers to the Pacific were frequently mobile and shifted between different homes.

13 Denoon, 'Re-Membering Australasia', 293.

14 Denoon, Mein-Smith and Wyndham, A History of Australia, New Zealand and the Pacific, 32.

15 Thompson, Australian Imperialism in the Pacific. 


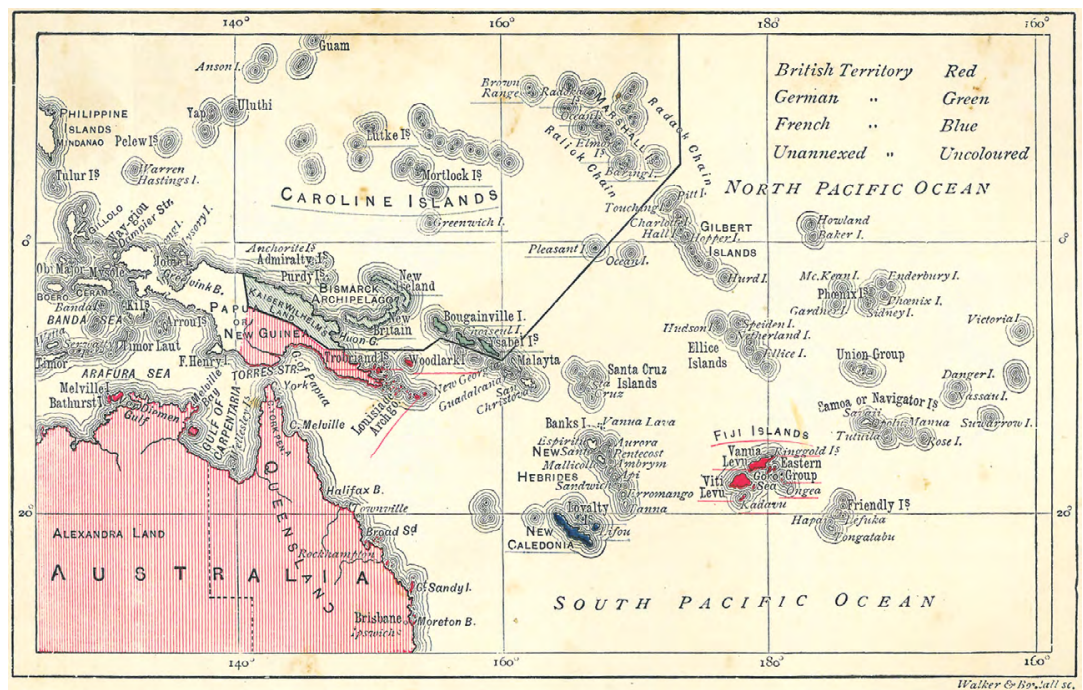

Figure 2: Map of the Pacific Islands.

Source: Julian Thomas, Cannibals and Convicts: Notes of Personal Experiences in the Western Pacific (Melbourne: Cassell \& Company, 1886).

The realities of colonial competition in the region from the 1880s onwards brought specific Islands into focus for certain members of the Australian colonies. Australian public interest in the Pacific Islands reached its peak during the 1880s and, rather than an empty South Sea, the imagined Pacific was filled with islands that were mapped in colour according to their colonial masters (see Figure 2). By 1885, a well-attended town hall meeting in Australia could be held on a Pacific issue. ${ }^{16}$ Concern about foreign threats was generated by German expansion throughout Tonga, Samoa and New Guinea, the transportation of French convicts to New Caledonia and overseas conflicts involving Britain, such as the 'Russian war scare' of $1884 / 1885$. Among the many perceived external threats, the French presence in New Caledonia and the New Hebrides prompted considerable debate in Australia during the late nineteenth century. These issues were used by the Australian federation movement to highlight the need for a foreign policy that was independent of Britain and, in some cases, for the formation of Australian imperialism in the Pacific that was based on the United States' (US) 'Monroe Doctrine'. This policy, which prohibited foreign annexations in the Americas, was adapted by Australians

16 Luke Trainor, British Imperialism and Australian Nationalism: Manipulation, Conflict, and Compromise in the Late Nineteenth Century (Melbourne: Cambridge University Press, 1994), 18. 
and applied to the region of Melanesia. As early as 1869, The Age had declared 'the manifest destiny of Australia, to employ an Americanism, is to colonise and subdue the islands of Melanesia'. ${ }^{17}$ In addition to the contested Pacific Island territories, the Australian colonies were interested in strengthening pre-existing relationships in the more secure British territories of Papua, Fiji and the Solomon Islands-relationships that were based predominantly on trade and commerce.

The Australasian colonies discussed the political future of the Pacific Islands during periodic meetings, such as the Colonial Conferences held in London in 1887, 1894 and 1897. These negotiations between the colonies and the British Colonial Office included topics such as political alliances and treaties, trade agreements and financial support, in which the Pacific Islands became important bargaining chips. These inter-colonial alliances were fluid and fragile, especially while the Australian colonies and New Zealand competed for greater influence in the region. Individual politicians could also play leading roles in advancing colonial ambitions in the Pacific. Notable Australian examples include Queensland premier Thomas McIlwraith, who ordered the annexation of New Guinea without permission on 4 April 1883, or Victorian premier James Service, who possessed an imperialistic vision for the country in the early 1880s. Some politicians even travelled to the Islands in pursuit of this cause, as New Zealand Prime Minister Richard John Seddon did in May 1900 to solicit agreements for New Zealand annexation. ${ }^{18}$

With Australia's Federation in 1901, the newly formed national government could begin to implement a distinctively Australian foreign policy; however, it remained constrained by interstate rivalries, economic pressures and allegiance to Britain. ${ }^{19}$ Australasia's relevance may have diminished, but the term continued to be appropriated by Australians to either articulate a British colonial affinity (a trans-Tasman relationship with New Zealand) or to describe Australia itself or an Australian sphere of influence in the region. In fact, Denoon, Mein-Smith and Wyndham argued that 'as Australian federation rendered "Australasia" obsolete, the continent and the seas and islands were more firmly cemented in

17 The Age, 14 August 1869, 2, nla.gov.au/nla.news-article188570311.

18 Steel, Oceania under Steam, 36; Richard John Seddon, The Right Hon. R. J. Seddon's (The Premier of New Zealand) Visit to Tonga, Fiji, Savage Island, and the Cook Islands, May 1900 (Wellington: New Zealand Government, 1900).

19 Thompson, Australia and the Pacific Islands, 65. 
the colonists' imaginations as a region, and indeed as their region'. ${ }^{20}$ In this region, the wider identity of Australasia was still being expressed well into the twentieth century. It included the Australian colony of Papua (then New Guinea), as well as the future possibility of New Zealand, the New Hebrides, Fiji and the Solomon Islands. This contested colonial relationship was visible to war correspondent Charles Bean in 1909 when he visited Fiji:

Fiji is really an Australian colony, though it does not care to be called so. The white men who govern Fiji come mostly from England; the white men who trade there, except a few English and British-Canadians, come all from Australia ... Now all the trade goes to Australia and New Zealand in two sharply-divided compartments. Red-funnelled Union boats take it, and bring next to nothing back. Nearly all the bananas and all the copra ... go in black-funnelled A.U.S.N. steamer Suva to Sydney; and nearly everything that Fiji uses comes from Sydney. That is Australia's interest in Fiji. ${ }^{21}$

Therefore, not only did the political legacy of the British empire influence Australian foreign policy and trade, it also continued to shape the paths that Australian travellers followed and the judgements that they made during their journeys. These travellers increasingly noted the strategic importance of certain Islands, with their observations specifying deep harbours, military fortifications and native police as evidence of growing colonial power and might. Further, improvements in technology not only encouraged colonial mobility-they also fostered colonial suspicions.

The borders defining spheres of influence in the Pacific Islands shifted over time, yet the most pervasive, persistent and unchanging conceptualisation of the Pacific Islands was a racialised one. The terms 'Melanesia' and 'Polynesia' were firmly rooted in Australian understandings of the Pacific region, denoting race rather than geographical location. ${ }^{22}$ The Islands of Melanesia included Papua and New Guinea, the Bismarck Archipelago, the Solomon Islands and Santa Cruz group, the New Hebrides, New Caledonia and Fiji. The Islands of Polynesia stretched from New Zealand

20 Denoon, Mein-Smith and Wyndham, A History of Australia, New Zealand and the Pacific, 186.

21 Charles Edwin Woodrow Bean, With the Flagship of the South (Sydney: William Brooks, 1909), $62-3$.

22 Serge Tcherkezoff, 'A Long and Unfortunate Voyage Towards the "Invention" of the Melanesia/ Polynesia Distinction 1595-1832', The Journal of Pacific History 38, vol. 2 (2003): 176, doi.org/10.1 080/0022334032000120521. 
in the south, to Easter Island in the east and to Hawai' $\mathrm{i}$ in the north. Twentieth-century Australians frequently described the Pacific in terms of this racial binary, omitting the original categories of Malaysia (which was considered part of Asia) and Micronesia (which was too distant). This racialised conception of the Pacific Islands was reflected in Australian travel accounts; they increasingly advocated a scientific understanding of race as being immutable and situated Pacific Islanders as being inferior and static. This resonated with early European conceptions of the Pacific Islands as being a space for scientific discovery, which described the Pacific Islander as a 'passive receptacle of observation'. ${ }^{23}$ It also encouraged stereotyping. Science and race permeated Australian travel writing, particularly in the texts describing Melanesia, and were convenient tools for justifying colonial exploitation and governance. Travel writing informed, and was in turn informed by, a series of domestic racial policies that were designed to protect the nation from foreign immigration, known collectively as the White Australia policy. Historians have tended to focus on how this policy was informed by fears of Asian immigration; presently, less research has been conducted to explore the Pacific evidence. The Immigration Restriction Act (1901) and the Pacific Island Labourers Act (1901) outlined Australia's official policy towards Pacific Islanders-and the consequences of these regulations were most keenly felt in the shipping trade, which was forced to privilege white labour over Islanders on government ships and ships with government contracts. ${ }^{24} \mathrm{~A}$ more balanced account of the White Australia policy must acknowledge the role that Polynesian and Melanesian tropes played in shaping popular public opinion about race.

Australian travellers continued to imagine the Pacific Islands according to the literary and scientific legacies that were left by their European predecessors, and popular notions of the South Seas, Polynesia and Melanesia remained unquestioned by most. However, an increasing number of travellers during the interwar period began to undermine popular tropes about the Pacific Islands. As more Australians travelled further abroad, there were more possibilities for cross-cultural encounters that undermined conventional stereotypes of the Pacific. The acquisition of the New Guinea mandate in 1920 also redefined Australia's geographical conception of the Pacific and demanded the growth of a greater international consciousness within Australia. Travel writing during the

23 Paul Sharrad, 'Imagining the Pacific', Meanjin 49, no. 4 (1990): 597.

24 Lake, 'The Australian Dream of an Island Empire', 410-24. For more information regarding the importance of Pacific Islander labour on the shipping trade, see Steel, Oceania under Steam. 
1920s and 1930s witnessed the term 'Pacific' being used more commonly than previous regional descriptors such as 'South Seas' or 'Australasia'; this evidences a greater recognition of the Pacific Islands being a shared and contested colonial space, especially in light of Japanese imperial ambitions in the region. This claim has been supported by recent studies of Australians' participation in pan-Pacific organisations in the 1920s and 1930s, which originated from US efforts that encouraged the notion of a 'new Pacific' as being a sphere of influence that was separate from Europe-one in which the US could play a leading role. ${ }^{25}$

\section{Looking Beyond the South Seas}

Some parts of the Pacific Island region did not feature as prominently in popular Australian perceptions of the South Seas, such as the North Pacific, New Zealand, Papua and New Guinea. With the exception of Hawai' $i$, the North Pacific region was rarely the subject of Australian travel writing, reflecting the minimal level of Australian engagement with, and interest in, the region. Intermittent Australian business ventures in the Marshall Islands and Kiribati failed to gain traction because of the region's geographical distance from Australia and its closer colonial associations with Japan and the US.

Across the Tasman Sea, New Zealand grew distinct from Australia in its relationship with the Pacific Islands and its indigenous Maori population. Having chosen not to be part of Australia's Federation in 1901, New Zealand articulated its own Pacific destiny in the early twentieth century. New Zealand nationalists advocated a nation that was superior to Australiaone born of free settlers rather than convicts and one with an indigenous people who were considered superior to the Aboriginal Australians. ${ }^{26}$ Having gained the Cook Islands in 1901, New Zealand aspired to add Fiji, Samoa and Tonga to its colonial acquisitions in the Pacific due to claims of scientific evidence of Polynesian homogeneity (with New

25 Tomoko Akami, Internationalizing the Pacific: The United States, Japan, and the Institute of Pacific Relations in War and Peace, 1919-45 (New York: Routledge, 2002); Fiona Paisley, Glamour in the Pacific: Cultural Internationalism and Race Politics in the Women's Pan-Pacific (Honolulu: University of Hawai'i Press, 2009).

26 Denoon, Mein-Smith and Wyndham, A History of Australia, New Zealand and the Pacific, 32-3; Angus Ross, New Zealand Aspirations in the Pacific in the Nineteenth Century (Oxford: Clarendon Press, 1964); Angus Ross, ed., New Zealand's Record in the Pacific Islands in the Twentieth Century (London: Hurst, 1969). 
Zealand located at the southernmost tip of the 'Polynesian triangle'). New Zealand colonialists established a more equitable relationship with the Maori population than Australians did with their country's Indigenous population; New Zealand 'became the growth pole for Polynesia South of the equator, as well as that region's leading centre for technical and higher education', with its openness to Polynesians starkly contrasting the racialised immigration policies of Australia. ${ }^{27}$ By comparison, Australians displayed little political interest in the Polynesian Islands, with many travelling to this region as tourists.

For Australian travellers, New Zealand was not often considered part of the South Seas, despite its location and Maori cultural origins. Chemist Charles Agar Atkin exemplified many Australian travellers who overlooked the island characteristics of New Zealand during his travels up the east coast to Fiji. He instead focused on the country's European architecture, public works and modern transportation, comparing its rate of progress to that of the Australian colonies. ${ }^{28}$ In addition to its cities, New Zealand's natural scenery (particularly Rotorua's thermal springs) provided popular tourist attractions. Maori were occasionally mentioned, though usually in comparison to other Pacific Islanders and in reference to their assumed superior status as Polynesians. For example, when John Cromar visited Honolulu, he noted that 'the Hawaiians were a very superior type of native, and similar to the Maoris of New Zealand, being light-skinned, and having long straight hair and perfect physique'. ${ }^{29}$ Strangely, Australian travellers were more willing to compare Maori with Pacific Islanders than to draw similar comparisons with Aboriginal Australians. In fact, comparisons between Aboriginal Australians and Pacific Islanders rarely appeared in Australian travel writing. It is unclear whether this was because Aboriginal Australians did not fit into the exotic stereotypes or racial hierarchies of the Pacific, or because of the official government policies in Australia that encouraged the segregation and displacement of Indigenous communities.

27 Denoon, 'Re-Membering Australasia', 301; Kerry R Howe, Race Relations: Australia and New Zealand: A Comparative Survey 1770's-1970's (Wellington: Methuen Publications, 1977).

28 Charles Ager Atkin, A Trip to Fiji via East Coast of New Zealand (Melbourne: Massina, 1885).

29 John Cromar, Jock of the Islands: Early Days in the South Seas: The Adventures of John Cromar, Sometime Recruiter and Lately Trader at Marovo, British Solomon Islands Protectorate, Told by Himself (London: Faber \& Faber, 1935), 20. The only exceptions to this are George Robertson Nicoll, Fifty Years' Travels in Australia, China, Japan, America, Etc., 1848-1898 (London: George Robertson Nicoll, 1899) and Arnold Safroni-Middleton, Tropic Shadows: Memories of the South Seas, Together with Reminiscences of the Author's Sea Meetings with Joseph Conrad (London: The Richards Press, 1927). 
The only other times that Australian travel accounts mentioned New Zealand involved the intention to observe (or challenge) the country's role as a colonial power in the Pacific. In Percy S Allen's 1920 handbook, New Zealand's colonial rule of Samoa was deemed ineffective due to its poorly trained officials:

The average New Zealand official in Samoa does not command the respect of the natives. He lacks prestige, has little education, and is without that traditional upbringing and savoir vivre that, for example, usually distinguishes the British Colonial Office official. ${ }^{30}$

Perhaps New Zealand's omission from the accounts of the South Seas was because it was perceived as less exotic-whether due to its European features, its location, its climate or its more developed tourism industry. Travel writer Elinor Mordaunt simply chose to avoid discussing New Zealand because it 'has been too much written about for me to tackle it'. ${ }^{31}$

In contrast, Australians' significant long-term contact with Papua and New Guinea since the late nineteenth century has created a vast archival record of Australian travel, some of which has been explored by Nigel Krauth, Clive Moore and Hank Nelson. ${ }^{32}$ The greatest test of Australia's colonial abilities was in the territories of Papua and New Guinea, which were limited realisations of a much broader Australian imperial vision. The territory of Papua comprised the south-eastern quarter of the island of New Guinea, which became a British protectorate in the year 1884 and

30 Percy S Allen, Stewart's Handbook of the Pacific Islands: A Reliable Guide to All the Inhabited Islands of the Pacific Ocean-For Traders, Tourists and Settlers, with a Bibliography of Island Works (Sydney: Steward McCarron, 1920), 13.

31 Elinor Mordaunt, The Venture Book (New York: The Century Co., 1926), 298. See also Lydia Wevers, Country of Writing: Travel Writing and New Zealand, 1809-1900 (Auckland: Auckland University Press, 2002).

32 Nigel Krauth, ed., New Guinea Images in Australian Literature (St Lucia: University of Queensland Press, 1982); Nigel Krauth, 'The New Guinea Experience in Literature: A Study of Imaginative Writing Concerned with Papua New Guinea, 1863-1980' (PhD thesis, University of Queensland, 1983); Clive Moore, James Griffin and Andrew Griffin, eds, Colonial Intrusion: Papua New Guinea, 1884 (Port Moresby: PNG Centennial Committee, 1984); Clive Moore, New Guinea: Crossing Boundaries and History (Honolulu: University of Hawai'i Press, 2003); Hank Nelson, 'European Attitudes in Papua, 1906-1914', in The History of Melanesia, ed. KS Inglis (Port Moresby and Canberra: University of Papua and New Guinea and The Australian National University, 1969); Hank Nelson, 'Our Boys up North: The Behaviour of Australians in New Guinea', Meanjin Quarterly 32, no. 4 (1973): 441-3; Hank Nelson, Black, White and Gold: Goldmining in Papua New Guinea, 1878-1930 (Canberra: ANU Press, 2016), doi.org/10.22459/bwg.07.2016; Hank Nelson, 'Looking Black: Australian Images of Melanesians', in The Pacific War in Papua New Guinea: Memories and Realities, ed. Yukio Toyoda and Hank Nelson (Tokyo: Rikkyo University, Centre for Asian Area Studies, 2006). 
was then formally annexed as British New Guinea four years later. In 1906, Australia became responsible for British New Guinea's administration. The north-eastern part of the island of New Guinea and several outlying Islands (including the German-named Bismarck Archipelago, New Britain and New Ireland) were known as German New Guinea. It was a protectorate from 1884 to 1914 , when it fell to Australian forces following the outbreak of World War I. From then, it was known as the Trust Territory of New Guinea, given to Australia as a League of Nations mandate (along with Nauru) in 1920. In 1949, the territories of Papua and New Guinea were combined. The Dutch claim to the western half of New Guinea remained unchallenged by Germany, Britain and Australia.

The first large-scale movement of Australians to Papua and New Guinea began due to the search for gold. Initial prospecting in the 1870 s offered mixed rewards, but by the 1890s, greater numbers of Australian diggers were sailing north. Gold was the main export of the territories of British New Guinea and Papua until 1916, and by 1940, it constituted 80 per cent of the mandated territory of New Guinea's exports. ${ }^{33}$ In the footsteps of these Australian diggers followed colonial officials, traders, agriculturalists, opportunists and tourists. By 1906, approximately 700 Europeans resided in the Australian territory — mostly miners, missionaries or government officials, whose contradictory interests were the source of frequent comment. ${ }^{34}$ These travellers wrote accounts that informed Australians about the country, complementing other news articles and official reports. Included in these accounts were the adventure literature of frontier patrols, the propaganda of Sunday school literature, the memoirs of missionaries and public officials, several handbooks and promotional materials, and a growing body of literature written by professional travel writers. ${ }^{35}$ So vast is the scale and diversity of the literature and the region it describes that it warrants its own dedicated study—and in this book, only a brief summary is provided of the significant role that Papua and New Guinea played in contributing to Australian perceptions of the broader Pacific Islands (particularly the evaluations of Australian colonial rule).

\footnotetext{
33 Nelson, Black, White and Gold, vi, 114.

34 Nelson, 'European Attitudes in Papua', 593.

35 For a bibliography of Australian biographical writing about Papua and New Guinea, see Nelson, 'Lives Told: Australians in Papua and New Guinea'.
} 
Papua and New Guinea occupied their own place in European and Australian imagining, distinct from the South Seas, partly due to their geography and political status. Due to their difficult terrain and relatively late contact with Europeans compared to the Islands of the eastern Pacific, early narratives of Papua and New Guinea instead transplanted descriptions of the interiors of Africa, Asia and South America, describing mythical creatures, savage inhabitants and hidden fortunes. ${ }^{36}$ Australian representations of Papua and New Guinea shared close similarities with the depictions and tropes of Melanesia in general, which are discussed in detail throughout this book. Images of 'New Guinea natives', either elaborately decorated or brandishing weapons, were regularly reproduced in books and magazines to emphasise Pacific exoticism and masculine savagery (see Figure 3). In other cases, this was juxtaposed with images of women and children (see Figure 4) to suggest innocence and justify patriarchal colonialism in the region. Max Quanchi's comprehensive study of images of the territory outlines the ways in which people, objects and designs were indiscriminately attributed to other Islands in the Pacific in print culture and in film. ${ }^{37}$ But unlike the smaller islands of the South Seas, many of which could be easily crossed or circumnavigated, the New Guinean mainland could only be probed by arduous journeys up rivers or across mountain ranges. Papua and New Guinea was thus popularly regarded as the 'last unknown'-a phrase that was coined in Karl Shapiro's wartime poem and that was later used as the title of a history by Australian Gavin Souter in $1963 .{ }^{38}$ Consequently, Papua and New Guinea were places of extremes within the broader Pacific imagining, lands 'of phantasmal imaginings and unexplainable nightmares'. ${ }^{39}$

36 See Chris Ballard, 'Collecting Pygmies: The "Tapiro" and the British Ornithologists' Union Expedition to Dutch New Guinea, 1910-1911', in Hunting the Gatherers: Ethnographic Collectors, Agents and Agency in Melanesia, 1870s-1930s, ed. Michael O'Hanlon and Robert L Welsch (New York: Berghahn Books, 2000), 127-54, doi.org/10.2307/j.ctt1x76fh4.11; Chris Ballard, 'Strange Alliance: Pygmies in the Colonial Imaginary', World Archaeology 38, no. 1 (2006): 133-51, doi.org/ 10.1080/00438240500510155; Chris Ballard, 'The Art of Encounter', 221-58.

37 Max Quanchi, Photographing Papua: Representation, Colonial Encounters and Imaging in the Public Domain (Newcastle: Cambridge Scholars Publishing, 2007), 93.

38 Karl Shapiro, V-Letter and Other Poems (New York: Reynal \& Hitchcock, 1944), 10; Gavin Souter, New Guinea: The Last Unknown (Sydney: Angus \& Robertson, 1963).

39 Arnold Safroni-Middleton, In the Green Leaf: A Chapter of Autobiography (London: Fortune P, $1950), 125$. 
1. FLUID BOUNDARIES AND AMBIGUOUS IDENTITIES

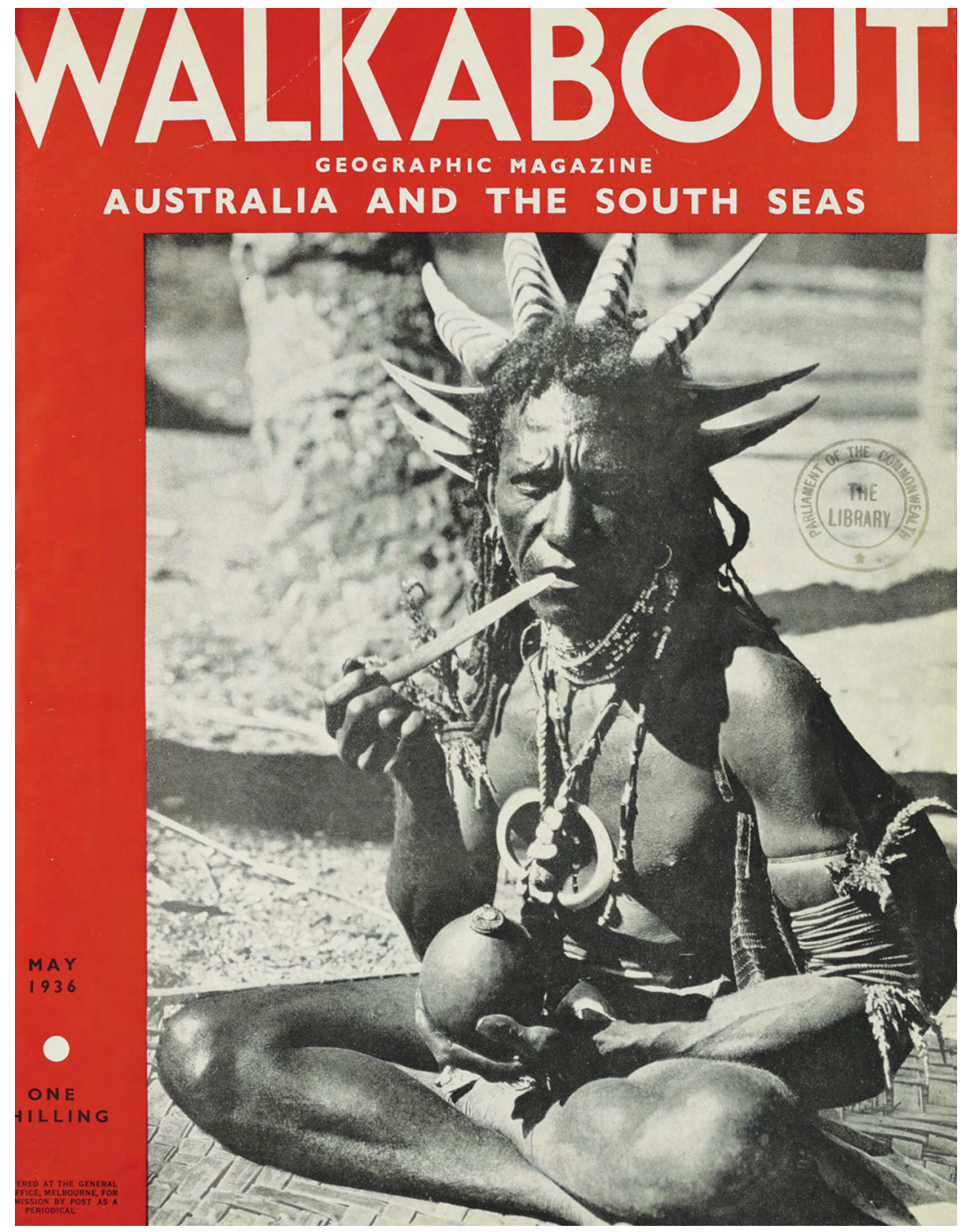

Figure 3: New Guinea Native.

Source: Front cover of Walkabout 2, no. 7 (May 1936). Image courtesy of the Australian National Travel Association. 


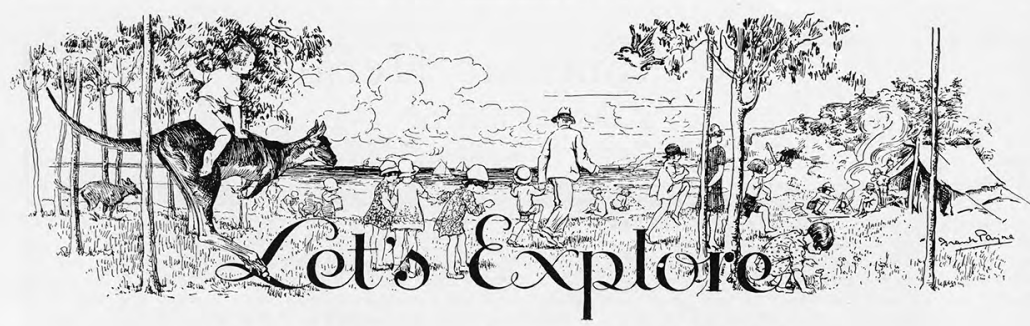

\section{In New Guinea Wilds}

Australia's Mandated Territory ORTH of Australia lies the enchanted land of Papua and New
Guinea, where strange native races still follow quaint customs. Waving coconut palms, blue lagoons and grim, rugged mountain ranges lend beauty and mystery to their surroundings. From Australian ports comfortable steamers carry tourists for winter From Australian ports comfortable steamers carny tourists for winter Samarai, Rabaul, Salamoa, Woodlark Island and innumerable places of interest.

The Mandated Territory includes 72,000 square miles of the mainland of New Guinea and thousands of islands large and small. New Britain covers 13,000 square miles, while the very smallest are mere specks of coral, a few square yards in extent.

The most important article of food and commerce is the product of the coconut. The natives are engaged in preparing the copra and are employed loading the vessels.

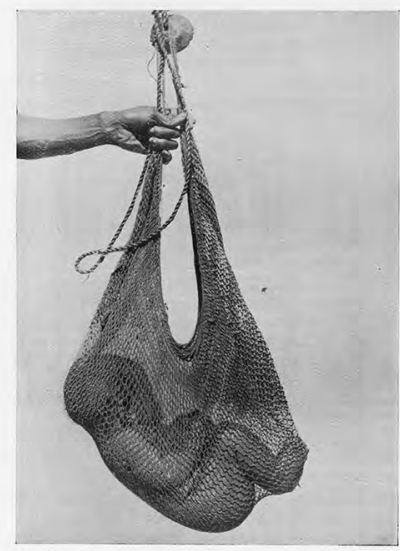

A New Guinea baby's cradle, woven from special grasses which are mosquito proot.

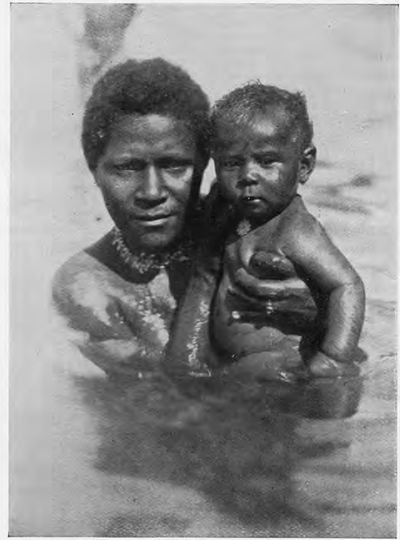

Mother and baby enjoy their morning dip together at Talasea. New Britain. than.

Port Moresby, the capital, is built near a beautiful harbour, and behind the township towers the great peak of Mt. Victoria $(13,200 \mathrm{ft}$.) in the Owen Stanley Range. Not far from the town are the beautiful Rona Falls and the tree houses of the Ikeri villages.

Samarai is the second largest township and is situated on an island a short distance from the mainland. Beautiful crotons grow in profusion and bright many-coloured trees line the road.

Rabaul, the capital, lies on the shores of a pretty bay, at the ent of which are hot sulphur springs and nearby are the islands of Matupi Woodlark Island is another lovely spot. Gold mining has been carried on in this district.

Salamoa is the port of call for the goldfields of Edie Creek and Bulolo, which are seven days march inland, over mountainous country. Native boys, who carry loads of $50 \mathrm{lbs}$. each are employed for transport work, and when the weather permits the aeroplane service is used. The goldfield was discovered in 1921.

Figure 4: Let's Explore in New Guinea Wilds Australia's Mandated Territory.

Source: BP Magazine (June-August 1930): 51. 
As Australian narratives of settlement gradually replaced those of exploration, Papua and New Guinea became a 'testing-ground for the strength of the Australian character' in the 1900s. ${ }^{40}$ It was also in these territories that Australian imperial ambitions were most fully enacted until 1975. As a result, there was a proliferation of accounts by government officials and district officers and these territories became a standard by which Australian rule was appraised. Australian parliamentarians emphasised a clear responsibility for the territory in 1901, eager to secure the transfer of British New Guinea to Australian control. In the first session of Parliament, Prime Minister Edmund Barton hoped that 'New Guinea is to be a territory, perhaps, a State of this Commonwealth'. ${ }^{41}$ In contrast to the attitudes towards the Northern Territory, an optimism existed for the notion that white settlement and indigenous protection could occur simultaneously. As Charles McDonald, a parliamentarian, noted in 1901: 'We know that the treatment of the aborigines in Australia has been a blot upon Australian history. I hope that it will not be repeated in the case of British New Guinea. ${ }^{42}$ Such comparisons made by Australian government officials regarding the Indigenous inhabitants of Australia and those of British New Guinea have likely influenced travellers' observations of the territory. These observations are distinct from travel writing about the rest of the Pacific region, which rarely mentioned Australian Aboriginals.

Australia's responsibility in New Guinea was re-emphasised in 1920 with the award of the League of Nations mandate, which made Australia accountable to a global audience. For example, this meant that, in practice, only colonial officers who worked in Papua and New Guinea received specialised training in anthropology, geography and hygiene from 1925, despite the welfare of Papuans and Aboriginal Australians frequently coming under the control of the same ministerial office. ${ }^{43}$ Despite this positive rhetoric, racial discrimination continued to underscore Australia's relations with Papua and New Guinea, as Alfred Deakin acknowledged in 1901: 'A "White Australia" may exist across the straits, but a "Black New Guinea" the territory now is and must always remain. ${ }^{44}$

40 Krauth, New Guinea Images in Australian Literature, xiv. See also Lake, 'The Australian Dream of an Island Empire', 410-24.

41 Australian Parliamentary Debates, House of Representatives, Vol. 6 (1901-02), 7079-91.

42 Australian Parliamentary Debates, House of Representatives, Vol. 6 (1901-02), 7411-2.

43 Thompson, Australia and the Pacific Islands, 74-5.

44 Morning Post, 31 December 1901. 
Although Australian politicians may have been confident about the role that Australians played in Papua and New Guinea, individual travellers were much more uncertain. As Hank Nelson argued, many people believed in the racial dogma of the day, yet few had the experience of close contact with other people; their understanding of the territory and their responsibilities compounded this rift, making many uncertain about whether Papua and New Guinea constituted a foreign country or an Australian frontier. ${ }^{45}$ This uncertainty was reflected in travellers' observations of the indigenous peoples and in their superficial comparisons with Australian Aboriginals. In general, Australians were assured of their superiority to the indigenous people and were confident that they were better and more humane colonisers than other Europeans. Realistically, they were inexperienced and unsure about how to handle the supposed 'inferiors'. ${ }^{46}$ Therefore, for the post-World War I Australian travellers who increasingly questioned the merits of their 'civilisation' and the allegedly 'superior' Australian coloniser, Papua and New Guinea presented the clearest opportunity for evaluating Australian efforts.

\section{Texts and Contexts}

Individual experiences of travel abroad could have a marked effect on travellers, but the process of writing and, in some cases, publishing an account of one's travels could introduce another set of constraints. An emerging literary culture in Australia was responding to the new notions and demands of Australian audiences, while also remaining aware of the popular conventions and accepted truths that were exhibited in European and US markets. Travel writing offers numerous examples of how travellers were aware of the popular genres of the day, the key texts that preceded them and the shifting demands of the Australian audience. Therefore, contextualising the experiences of travellers within their appropriate literary contexts is important. Jonathon Lamb's literary history of Pacific voyages emphasises the context of the metropolitan audience who consumed the narratives, highlighting how the accounts were dramatised and distorted. Rather than detailing scientific truth, firsthand impressions magnified the uncertainties and anxieties

45 Nelson, 'Our Boys up North', 433.

46 Nelson, 'Our Boys up North', 440. 
of European society. ${ }^{47}$ Robert Dixon has been influential in addressing the discourse of travel writing as part of his advocation for a 'stronger postcolonial perspective in interdisciplinary Australian studies'. Dixon argued that text cannot be reduced only to ideology or to the nation-state and highlighted the role that commercial entertainment markets play in shaping texts. His text-based analyses demonstrate the hybridisation of Australian texts, acknowledge the discernment of Australian audiences and argue for a more nuanced understanding of the relationship between culture and governance that is 'contingent and mediated'. ${ }^{48}$

Publishing in books, magazines or newspapers was a convenient method for travellers to make a living, which likely explains the high proportion of journalists and professional writers within the corpus of Australian travel writers (approximately 20). Newcomers to the publishing industry would circulate multiple copies of the same or similar stories to various magazines so that they could establish a reputation. Publishers were aware of popular trends and current affairs and could satisfy periodic peaks of demand for news about the Pacific Islands with reports from recently returned travellers. Authors such as Frank Hurley, Ion Llewellyn Idriess and Frank Clune were clever marketers and capitalised on sponsorship and publicity on radio and in print. Others such as Grimshaw earned commissions from governments and businesses for their travel writing. It is thus important to consider these authors' revealing literary aspirations, though this is not the central focus of this book. Australian novelists who wrote about the Pacific were confident about a market in Australia, England and the US for sensational accounts of mysterious Islands. The international success of Australia's first Pacific travel writer at the turn of the century, Louis Becke, was a testament to this. Most writers were conscious of the characteristics of popular genres at the time, and the abundance of travel writing produced a need for travellers to distinguish themselves, even if this tended towards sensationalism. ${ }^{49}$

47 Jonathan Lamb, Preserving the Self in the South Seas, 1680-1840 (Chicago: University of Chicago Press, 2001), 6, 83.

48 Robert Dixon, Prosthetic Gods: Travel, Representation, and Colonial Governance (St Lucia: University of Queensland Press and API Network, 2001), 9. See also Robert Dixon, Writing the Colonial Adventure: Race, Gender, and Nation in Anglo-Australian Popular Fiction, 1875-1914 (New York: Cambridge University Press, 1995), doi.org/10.1017/cbo9781139085038; Robert Dixon, 'What was Travel Writing? Frank Hurley and the Media Contexts of Early Twentieth-Century Australian Travel Writing', Studies in Travel Writing 11, no. 1 (2007): 59-81, doi.org/10.1080/13645145.2007.9634819.

49 Broinowski, The Yellow Lady, 23; Wevers, Country of Writing, 156. 
Whether writing for family, friends, validation, fame or fortune, travellers returning home who wished to publish their diaries or notes had to negotiate a competitive market in Australia. The changing literary landscape between 1880 and 1941 correlates with shifting representations of the Pacific Islands in Australian travel writing. As national literacy improved and printing became cheaper, the 1870 s and 1880s witnessed a growing mass market for books in Australia and an increasing number of professional writers. ${ }^{50}$ Since few book publishers existed in Australia, periodicals were often de facto publishers. A trans-Tasman print culture entailed that writing was regularly shared between Australia and New Zealand, as was authorship. For both Australian and New Zealand writers of this period, literature was closely tied to British publishers and themes. ${ }^{51}$

There were several consequences to being situated on the periphery of the British publishing empire. Helen Bones' analysis of newspaper literary reviews reveals that the reception of travel writing at home and overseas affected the way that it was interpreted, which is especially significant for Australia and New Zealand, as the two countries 'have historically been anxious about forging an independent, authentic, national identity'. She thus argued that 'fictionality or authenticity is dependent on identity politics as well as genre. ${ }^{52}$ This may explain why travellers were reluctant to self-identify as Australian, or why they would sometimes call themselves British, Britisher, colonial or Australasian. This shared identity was encouraged by the books and magazines about the Pacific Islands that were distributed among the colonies, which included Australian, New Zealand and British authors.

Several authors recognised that the chances of succeeding as a professional writer were greater in London. Many Australian authors chose to move to Europe in search of employment and often stayed there-such as Jack McLaren, a Melbourne-born author who wrote extensively about his Pacific travels in the late 1890s and who moved to London in 1925 when he was 39 to pursue his writing career. McLaren found success in London and established his reputation as an author, publishing most of his fictional work about the Pacific and working for the British Broadcasting

50 White, Inventing Australia, 89.

51 As discussed by Elizabeth Morrison in Dixon, Writing the Colonial Adventure, 197. See also Helen Bones, 'New Zealand and the Tasman Writing World, 1890-1945', History Australia 10, no. 3 (2013): 129-48, doi.org/10.1080/14490854.2013.11668484.

52 Helen Bones, 'Travel Writers and Traveling Writers in Australasia: Responses to Travel Literatures and the Problem of Authenticity', Journeys 17, no. 2 (2016): 74-94, doi.org/10.3167/jys.2016.170205. 
Corporation. In fact, some Australian authors were considered British by their readers because their books were published in London. ${ }^{53}$ One example is Eric Muspratt, a twice-serving Australian war veteran and one-time plantation manager in the Solomon Islands in 1920, whose death went unnoticed in Australia yet was remembered in England. According to the biography by Bruce Grant, this was likely because 'Muspratt played up to the wealthy and influential English, especially in the newspapers, in a manner they expected. He wanted the publicity and they were happy to give it'. ${ }^{54}$ Muspratt's life is one example that reveals how the cultural isolation of Australia affected its writers, though Helen Bones cautions against assuming that all writers in the 'Tasman writing world' were disadvantaged by distance. ${ }^{55}$

Pressure from British publishers could also alter the content of the texts, though it was uncommon to acknowledge this explicitly. One rare example is provided by Caroline David in a collection of her personal papers, in which she commented on having to remove 'a heap of nice but naughty things' during the publishing process for her 1897 diary about a trip accompanying her husband's scientific mission to Funafuti. David's experience was consequently modified for British audiences, which she noted disparagingly: 'The worst of it is that in considering the delicacy of the spiritual and moral constitution of the Brit. Public, one is apt to lose the vividly truthful picture of the island as it really is'. ${ }^{56}$ Publishing under her own name, it is likely that David's gender played a part in the choices made by the editor. David was one of a small group of female travel writers of the Pacific, but this imbalance may reflect the gender bias of the publishing industry rather than the travel patterns of Australians.

The publishing context within the Australian continent can also explain some of the general trends of Australians' Pacific travel writing. The number of travel accounts significantly increased from the $1890 \mathrm{~s}$ onwards, which may be explained by the expansion of steamship routes in the Pacific Islands and the economic growth and national optimism

53 David Carter, 'Transpacific or Transatlantic Traffic? Australian Books and American Publishers', in Reading Across the Pacific: Australia-United States Intellectual Histories, ed. Robert Dixon and Nicholas Birns (Sydney: Sydney University Press, 2010), 345.

54 Bruce Grant, ed., Arthur and Eric: An Anglo-Australian Story from the Journal of Arthur Hickman (Melbourne: Heinemann Australia, 1977), 211.

55 Helen Bones, 'New Zealand and the Tasman Writing World', 129.

56 Caroline David, 'Letter to Mrs Scott, 1898', Papers of the David Family, NLA MS 8890, Series 2, Folder 25, Canberra, National Library of Australia. 
exhibited up until 1914. A new literary culture was developing in Sydney at this time, led by The Bulletin and the establishment of new publishers. ${ }^{57}$ These included the Sydney bookstore Angus and Robertson (established in 1888) and the New South Wales Bookstall company, which began publishing around the same time. By 1922, Bookstall alone had published 120 authors and 200 titles and had sold 4.5 million copies, at a time when Australia's population numbered 5 million..$^{58}$ In this environment, Australian literature presented the newly federated nation as being young, pure and innocent, and-through the figure of the 'coming man'idealised a people who were superior to the British stock, who were shaped by the Australian climate and who were proven in sports and war. This idealisation was also shaped by popular racial assumptions regarding the superiority of Australians, both at home and abroad. Australian travellers in the Pacific influenced and incorporated these popular notions about race and nation that were circulating in Australian literature at the time.

Following the upheaval of World War I, a new urban and cosmopolitan middle class in Australia drove a simultaneous demand for travel and literature. Despite the economic impact of the Great Depression, approximately 24,000 Australians were travelling the world annually after World War I. ${ }^{59}$ This was the 'age of the tabloid press', as argued by Peter Kirkpatrick, when newspapers had to excite and entertain rather than simply inform. ${ }^{60}$ Facing increasing competition and a new 'segmented hierarchy of taste cultures', Australian publishers had to market their materials to a more diverse public, as argued by David Carter. ${ }^{61}$ This shift is evident in the use of titles that are distinctive from the traditional

57 Peter John Kirkpatrick, The Sea Coast of Bohemia: Literary Life in Sydney's Roaring Twenties (St Lucia: University of Queensland Press, 1992), 52.

58 Toni Johnson-Woods, 'Popular Australian Writing', in A Companion to Australian Literature Since 1900, ed. Nicholas Birns and Rebecca McNeer (Rochester: Camden House, 2007), 394. See also White, 'Travel, Writing and Australia'; R Wynn, ed., The Late Alfred Cecil Rowlandson: Pioneer Publisher of Australian Novels (Sydney: J. Sands, 1922); Jennifer Alison, Doing Something for Australia: George Robertson and the Early Years of Angus and Robertson, Publishers: 1888-1900 (Melbourne: Bibliographical Society of Australia and New Zealand, 2009); Linda S Crowl, 'Politics and Book Publishing in the Pacific Islands' (PhD thesis, University of Wollongong, 2008); Carol Mills, The New South Wales Bookstall Company as a Publisher: With Notes on Its Artists and Authors and a Bibliography of Its Publications (Canberra: Mulini Press, 1991).

59 Richard White, 'The Retreat from Adventure: Popular Travel Writing in the 1950s', Australian Historical Studies 28, no. 109 (1997): 92, 101, doi.org/10.1080/10314619708596045.

60 Kirkpatrick, The Sea Coast of Bohemia, 111.

61 David Carter, “Literary, but Not Too Literary; Joyous, but Not Jazzy”: Triad Magazine, Modernity and the Middlebrow', Modernism/Modernity 25, no. 2 (2018): 245-67, doi.org/10.1353/mod. 2018.0018. See also David Carter, Always Almost Modern: Australian Print Cultures and Modernity (North Melbourne: Australian Scholarly Publishing, 2013). 
cannibal or coral stereotypes of previous decades, such as South Sea Foam, Sinabada, The Black Musketeers, Stormalong, Backwash of Empire, No Longer Innocent and Wine-Dark Seas and Tropic Skies. These titles may also reflect a broader weariness of overused and exaggerated Pacific tropes that existed during the interwar period. This resonates with Andrew Hassam's claim that the Depression of the 1930s stimulated a more critical attitude in Australia and that it produced a literature that was marked by a greater cultural maturity. ${ }^{62}$

This cultural shift during the interwar period is also evident in the diverse content of magazines. An analysis of Australian magazines of the twentieth century reveals that 22 out of 85 titles were established during the interwar period. ${ }^{63}$ The Pacific content of Australian magazines in the early twentieth century generally focused on Australians' economic or social opportunities in the region, which was in addition to travel magazines that specifically promoted popular tourist destinations. Illustrations played an important role in these publications and travel writing-Max Quanchi has written extensively on the twin-barrelled effect of text and image in magazines and in illustrated weekend newspapers. ${ }^{64}$

Two magazines, BP Magazine and Walkabout, featured the most Pacific content. BP Magazine was unabashedly promotional material published by the Australian shipping company, Burns, Philp and Company, and emphasised the comfort and luxury of ocean travel while simultaneously publicising the experience as exotic and adventurous. Although directed at tourists and, in some cases, potential investors and settlers, the magazine's editors also marketed it as educational and informative material. For this reason, BP Magazine may be considered closely related to travel writing in style and purpose, especially since many of its articles were written by individual travellers who reported the observations that they made during their holidays in the region. Further details about the publication and its parent company will be discussed later in this book.

62 Hassam, Through Australian Eyes, 167.

63 'Australian Magazines of the Twentieth Century', AUSTLIT, www.austlit.edu.au/specialist Datasets/BookHistory/AustMag. See also Toni Johnson-Woods, Index to Serials in Australian Periodicals and Newspapers (Canberra: Mulini Press, 2001).

64 Max Quanchi, 'The Power of Pictures: Learning-by-Looking at Papua in Illustrated Newspapers and Magazines', Australian Historical Studies 35, no. 123 (2004): 37-53, doi.org/10.1080/10314 610408596271. 
Walkabout was a monthly geographic magazine that was published by the Australian National Travel Association from 1934 to 1974. It has been the subject of several studies-most recently by Anna Johnston and Mitchell Rolls, who argued that the magazine reveals key issues in Australia's cultural history and that it shaped understandings of Australia's place in the region. ${ }^{65}$ Walkabout published an equal number of images and stories about the Pacific as it did about Australia (nearly 400), and like other geographical magazines at the time, it blended anthropological information and tourism promotions. Images of Papua and New Guinea featured more frequently on the front covers of Walkabout than any other Pacific Islands, and the magazine reflected a general preoccupation with Australia's colonial mandate. Johnston and Rolls recognised that many of the magazine's contributions were travel accounts, and their conclusions echo the findings of the study in this book-although 'paternalist and assimilationist policies are regularly reflected' in the Pacific content of Walkabout, the Pacific Islands were given 'varied, often conflicting treatment by different writers'.

Walkabout was notable because it was one of the few travel magazines that regularly featured Pacific and Australian content together. Frequent images of Aboriginal Australians placed next to Pacific Islanders prompted Johnston and Rolls to identify a 'rhetoric of neighbourliness' that permeated Walkabout, but they provided limited evidence of explicit comparisons between the two. ${ }^{66}$ Although pictorial comparisons may have been common in Walkabout, writers rarely compared Indigenous Australians and Pacific Islanders, or their environments, in the written text of the 1930s volumes — which is a surprising omission, given the magazine's educational and anthropological overtones. Nonetheless, the case of Walkabout highlights how travel writing was intertwined with illustrated magazines and newspapers and how it produced diverse and, at times, ambiguous results.

Magazines are also useful indicators of readership and circulation, which are difficult details to determine in travel writing monographs. For example, Victorian Kuttainen and Sarah Galletly used Walkabout to make broader generalisations about 'middlebrow orientalism' in

65 Anna Johnston and Mitchell Rolls, Travelling Home, Walkabout Magazine and Mid-TwentiethCentury Australia (London: Anthem Press, 2016).

66 Johnston and Rolls, Travelling Home, 174-6. 
Australian interwar magazines and its reception by Australian readers. ${ }^{67}$ The notion of the 'middlebrow' can apply to the texts themselves and to a collective readership; it is also useful for considering the inherent tensions within travel writing, as writers blended genres and styles from lowbrow and highbrow literature. Lowbrow literature drew from popular fictional tales and stereotypes to offer the unexpected and fantastical, while highbrow literature claimed an authority that was gained from firsthand experience and objective observations, justifying travel as an educational and informative activity of self-improvement. This middlebrow ideal was typified by statements like those made by BP Magazine, which claimed to 'phrase the fascination from these varying activities and cull from the Markets of the World the best in Literature and Art for the entertainment and interest of its readers' ${ }^{68}$ Richard White has described this preoccupation with 'respectability as rational recreation' as being a clear marker of the middlebrow. ${ }^{69}$ The Pacific Islands (as well as the vessels that transported people to them) may have been settings that encouraged this middlebrow sensibility in travel texts. ${ }^{70}$

The middlebrow readership should not be confused with the middle class, though middlebrow content may have reflected certain class issues or biases. Most authors in the study presented in this book belonged to the middle class; however, this may reflect the composition of the publishing industry rather than the travel patterns at the time. Australian travel writers were more likely to be middle- and upper-class Australians because they were well educated and literate and because they had the networks and means to access publishers. Whether this signifies that a Pacific consciousness was more prevalent among certain classes in Australia is unclear. There is some evidence to suggest so. Warwick Anderson highlighted this in his research on a group of Australasian liberal intellectuals who were obsessed

67 Victoria Kuttainen and Sarah Galletly, 'Making Friends of the Nations: Australian Interwar Magazines and Middlebrow Orientalism in the Pacific', Journeys 17, no. 2 (2016): 23-48, doi.org/ $10.3167 /$ jys.2016.170203.

68 'Editorial', BP Magazine 1, no. 1 (1928): 1.

69 Richard White, 'Armchair Tourism: The Popularity of Australian Travel Writing', in Sold by the Millions: Australia's Bestsellers, ed. Toni Johnson-Woods and Amit Sarwal (Newcastle upon Tyne: Cambridge Scholars Publishing, 2012), 183. See also Holland and Huggan, Tourists with Typewriters, 10; Richard White, 'Australian Journalists, Travel Writing and China: James Hingston, the "Vagabond" and G. E. Morrison', Journal of Australian Studies 32, no. 2 (2008): 238-9, doi.org/10.1080/ 14443050802056755; Christina Klein, Cold War Orientalism: Asia in the Middlebrow Imagination, 1945-1961 (Berkeley: University of California Press, 2003), 64.

70 Nicholas Halter, 'Ambivalent Mobilities in the Pacific: "Savagery" and "Civilization" in the Australian Interwar Imaginary', Transfers 7, no. 1 (2017): 34-51, doi.org/10.3167/TRANS.2017.070104. 
with the Pacific in the 1920s and 1930s, seeing the region as a place to learn about Australia's population problems. ${ }^{71}$ The emergence of a local literary bohemia in Sydney in the early twentieth century also suggests that class played a role in the development of literature about the broader Pacific region. ${ }^{72}$

\section{Articulating Australianness}

So, what can travel writing tell us about what it means to be Australian? Historians have highlighted the 'bushman', the soldier (also known as the 'digger'), the sportsman and the 'larrikin' as emblematic figures of Australian values; however, the way that the Pacific Islands reflected aspects of Australian character and concerns has yet to be fully explored. Setting aside the fact that travel writing highlights the diversity and individuality of Australians - and that the process of travelling abroad amplified the ambiguities and insecurities of individual and national identities-it is possible to make some broad generalisations about Australian travel writing in comparison to travel accounts that were written by authors of other nationalities. In this contested colonial space, Australian travellers re-positioned themselves in relation to other prominent imperial powers: the British, New Zealanders, German, French, Japanese and Americans.

The Oxford Book of Australian Travel Writing makes some claims about how Australian travel writing is distinct-namely, that it is distinguished by its obsession with cleanliness or a supposed 'casual seriousness'-but this risks oversimplification when considering the specific context of Australia's relationship with the Pacific. ${ }^{73}$ Compared to the crowded urban cities of Europe and Asia, the small villages and towns of Pacific Islands did not commonly evoke comments about cleanliness or sanitation. Rather, tropical disease was a more pressing concern for Australians. Similarly, the notion of 'casual seriousness' in Pacific travel writing is also questionable. Although the Pacific was promoted as a relaxed and leisurely destination, Australian travellers were conscious of their precarious position as colonisers and colonial subjects abroad, with their accounts frequently

71 Warwick Anderson, 'Liberal Intellectuals as Pacific Supercargo: White Australian Masculinity and Racial Thought on the Boarder-Lands', Australian Historical Studies 46, no. 3 (2015): 425-39, doi.org/10.1080/1031461x.2015.1071417.

72 Kirkpatrick, The Sea Coast of Bohemia, 52.

73 Pesman, Walker and White, The Oxford Book of Australian Travel Writing, xv, xxiii. 
appealing to British themes and sensibilities. British cultural values and literature strongly influenced the travel writing that was produced in the antipodes. The style of British travel writing in the Pacific specifically and in other locations more generally has been well studied. The bulk of theoretical scholarship on travel writing has focused on Anglophone European travel accounts since the sixteenth century. Holland and Huggan identified a 'cult of gentlemanliness in contemporary Anglophone travel writing'-a theme that was communicated to colonial readers in Australia and in the rest of the empire during the late nineteenth and early twentieth centuries through boyhood adventure tales, many of which that were set in the Pacific. ${ }^{74}$ Colonial Australians thus formed notions of racial superiority and civilisation that were based on British literature, and many of their notions of the Pacific region were based on British representations. These notions and the stereotypical British gentleman were only gradually modified by Australian writers into the 'coming man' that typified distinctly Australian values.

Overt displays of Australian patriotism were rare in travel writing. In some cases, the Sydney school of writers for The Bulletin newspaper and the Victorian-based Australian Natives Association influenced authors and travellers, such as Louis Becke, Jack McLaren and George Meudell. ${ }^{75}$ The 1917 diary of Australian sailor Chris Syvertsen while anchored in Suva aboard the HMAS Fantome is a rare example of a distinctively Australian 'voice'-one containing references to what he termed 'Australian Slanguage' and poems about what it meant to be Australian. ${ }^{76}$ Patriotic statements that distinguished Australia from England were more commonly stimulated by the presence of foreign threats, such as reactions to French colonial presence in the New Hebrides and New Caledonia or the Japanese expansion in the North Pacific. In some cases, travellers criticised the British empire, as Eric Baume did in his description of Fiji as a 'typical smug British colony $;{ }^{7}$ however, to advocate that Australia take the colonial mantle from Britain was usually a step too far. Therefore, travel accounts did not always mirror public opinion regarding Australia's

\footnotetext{
74 Holland and Huggan, Tourists with Typewriters, 6. See also Saxby, A History of Australian Children's Literature 1841-1941, 24; Pearson, Rifled Sanctuaries, 58; Brian V Street, The Savage in Literature: Representations of "Primitive" Society in English Fiction, 1858-1920 (London: Routledge, 1975), doi.org/10.4324/9781315617275; Dixon, Writing the Colonial Adventure.

75 John Hirst, The Australians: Insiders \& Outsiders on the National Character since 1770 (Melbourne: Black Inc., 2010), 11-13; Pearson, Rifled Sanctuaries, 78.

76 Chris Syvertsen, Private Record, PR01438 (Canberra: Australian War Memorial, 1917-1918).

77 Eric Baume, I Lived These Years (Sydney: George G. Harrap \& Co., 1941), 160.
} 
colonial ambitions in newspapers and political discourse, presumably because travel could evoke an uncertainty about the young nation's ability to rule over others.

The benefit of being on the periphery of the empire was that travellers were less constrained by British etiquette and social norms. As one female author noted in a private letter in 1898 , the view from the periphery could offer important truths for metropole readers:

A little wholesome truth might shock 'em [the British public], but might it not prove bracing? ... If I could afford it, I would risk publishing all the indelicate facts-because they are full of teaching which is needed — but I can't afford it—and so must let off the good souls who, in my estimation, so require a tonic. ${ }^{78}$

In this way, Australian writers shared much with their New Zealander neighbours. In her study of trans-Tasman print culture, Helen Bones noted that:

New Zealanders and Australians were able to use their colonial status as an advantage. There was a great deal of British interest in the 'colonial exotic', and British audiences were eager to read material on the subject. ${ }^{79}$

For this reason, she argued that scholars should consider trans-Tasman writers a collective rather than differentiate between Australians and New Zealanders.

However, there were also subtle differences between Australian and New Zealander travel writers. In his history of Fiji, Brij V Lal argued that during the interwar period, 'The New Zealanders thought of themselves as better, more refined representatives of colonial English culture, and the Australians were generally less respectful of the rituals and protocols of colonial life'. ${ }^{80}$ This distinction was clearer in colonies like Fiji, where Australians and New Zealanders had equally competing interests, as opposed to other British colonies like Samoa or Papua and New Guinea, where one country possessed more influence than the other. The works of Lydia Wevers, Helen Bones, Frances Steel and Anna Johnston have begun

78 David, 'Letter to Mrs Scott, 1898'.

79 Bones, 'New Zealand and the Tasman Writing World', 138. See also Denoon, Mein-Smith and Wyndham, A History of Australia, New Zealand and the Pacific.

80 Brij V Lal, Broken Waves: A History of the Fiji Islands in the Twentieth Century (Honolulu: University of Hawai'i Press, 1992), 106. 
to address the lack of research on New Zealand travel writing. ${ }^{81}$ Their studies address how New Zealand was connected to the Pacific Islands, arguably in a way that was distinct from Australia's connection. According to Denoon, Mein-Smith and Wyndham, 'Since the opening of the Suez Canal it [New Zealand] looked in a different direction from Australia to overcome its remoteness, across the Pacific rather than through Suez to Britain'. ${ }^{82}$ Although Australia was the commercial hub of the Pacific, it remained culturally distinct from it, while New Zealand embraced its Polynesian identity enthusiastically. Kerry Howe's discussion of the relationships between colonialists and Indigenous peoples in Australia and New Zealand identifies a more equitable relationship between the Pakeha (European) and the Maori population, in comparison to Australian settler relations with Indigenous Australians. This greatly influenced New Zealand perceptions of the Pacific Islands. ${ }^{83}$

This may explain why Maori would often feature in Australian travel accounts of the Pacific, while Aboriginal Australians were strangely absent. Although Aboriginal Australians were present in the travel accounts of the Australian continent, travellers rarely combined their continental travels with the Pacific Islands. ${ }^{84}$ This may reflect the practicalities of travel, as overland voyages and sea voyages are largely separate ventures. It may also highlight the popular beliefs of racial hierarchies at the time, with Aboriginal Australians considered racially inferior to Pacific Islanders. Or perhaps writers were reluctant to compare the romanticised and exoticised Pacific Islands to the realities of the large and harsh Australian continent. This would explain why travellers were reluctant to reference any familiar Australian people or places in their Pacific travel accounts. Only in certain accounts of Papua and New Guinea did Australian writers compare the inhabitants to Aboriginal Australians, with the motivating factor likely being Australia's colonial responsibilities in the territory.

Similarities between Australian, New Zealander and British travel writing did not only reflect shared cultural ties; the travel writing was also shaped by the nature of British colonialism in the region. British colonialism in the Pacific was generally characterised by an emphasis on settlement

81 Wevers, Country of Writing; Bones, 'New Zealand and the Tasman Writing World'; Bones, 'Travel Writers and Traveling Writers in Australasia'; Katie Pickles and Catharine Coleborne, eds, New Zealand's Empire (Manchester: Manchester University Press, 2015).

82 Denoon, Mein-Smith and Wyndham, A History of Australia, New Zealand and the Pacific, 197.

83 See Howe, Race Relations.

84 See Robert Clarke, Travel Writing from Black Australia: Utopia, Melancholia, and Aboriginality (New York: Routledge, 2015), doi.org/10.4324/9781315851129. 
and trade, as compared to other European colonial powers in the region (e.g. Germany and France) whose colonial systems have been portrayed as more accommodating than the British style of rule.

Germany's colonial reach extended to north-eastern New Guinea, Samoa and the Bismarck, Marshall, Caroline and Mariana Islands between 1884 and 1914, though its Pacific colonies were isolated and relatively insignificant compared to its African colonies. This meant that although German travel writing considered the Pacific Islands to be within a more global colonial project, Australian travel writers were much more focused on the Pacific as an important and immediate area of interest. Primarily focused on economic gains, the German colonies had a 'civilian tone' compared to other colonial powers in the region, with less military, official or missionary presence. ${ }^{85}$ They have been characterised by Lal and Fortune as 'rudimentary compared to the practised colonial cultures of Britain and France', and were 'neither racist nor nationalistic ${ }^{86}$ - a key point of difference compared to what was described in Australian literature at the time. Although German and Australian travel writing both featured race as a prominent theme, Germans went one step further and imagined similarities between Polynesians and Germans; their writing was 'organised around tropes of empathy with the colonised', as argued by Russell Berman. ${ }^{87}$ Such a notion signified that unlike its African colonies, Germany's colonial practices in the Pacific recognised indigenous models of governing. ${ }^{88}$ This does not mean that German colonial rule was always benevolent. As Stewart Firth demonstrated in his history of German New Guinea, the territory's colonial rule could be erratic and harsh, and Australian writers were eager to portray the German trader as ungentlemanly. ${ }^{89}$

85 Sara Friedrichsmeyer, Sara Lennox and Susanne Zantop, eds, The Imperialist Imagination: German Colonialism and Its Legacy (An Arbor: University of Michigan Press, 1998), 11; Peter J Hempenstall, Pacific Islanders under German Rule: A Study in the Meaning of Colonial Resistance (Canberra: ANU Press, 2016), 22-3, doi.org/10.22459/piugr.06.2016.

86 Brij V Lal and Kate Fortune, eds, The Pacific Islands: An Encyclopaedia (Honolulu: University of Hawai'i Press, 2000), 236.

87 Berman termed this concept as 'salvage colonialism'; Russel A Berman, Enlightenment or Empire: Colonial Discourse in German Culture (London: University of Nebraska Press, 1998), 10.

88 Miriam Kahn and Sabine Wilke, 'Narrating Colonial Encounters: Germany in the Pacific Islands', The Journal of Pacific History 42, no. 3 (2007): 296, doi.org/10.1080/00223340701691975. See also Tracey Reimann-Dawe, 'German Travel Writing on Africa 1848-1914', in German Colonialism and National Identity, ed. Michael Perraudin and Jürgen Zimmerer (New York: Routledge, 2011), 21-32. 89 Stewart Firth, New Guinea under the Germans (Carlton: Melbourne University Press, 1982); Dirk HR Spennemann, "Vell, I don't call dot very shentlemanly gonduck”: The Portrayal of Germans as Ungentlemanly South Sea Traders in Louis Becke's Short Stories', Pacific Asia Inquiry 5, no. 1 (2014): 107-29. 
French engagement in the Pacific region occurred on a greater scale and within a longer time frame than German engagement, with colonies created in eastern Polynesia, New Caledonia and the New Hebrides; however, its informal empire of traders and residents did not match the British network in size and scale. Matt Matsuda characterised French imperialism as being 'more fragmentary than comprehensive' and as focusing on alliance and accommodations rather than emphasising settlements and plantations as the British did. ${ }^{90}$ For this reason, Australian travel writers offered more detailed descriptions of the economic and colonial processes at work than French writers, and they did not display the same degree of 'emotional sensibility' that Matsuda identified as a common feature of French texts. The influence of French explorers and writers was significant for Australians, with people like de Bougainville, Diderot, Loti and Gauguin enshrining Polynesia as a tropical paradise in the popular imagination. Of the French colonies, Australians were most concerned with the French colonial presence that was closest to Australia's shore (i.e. New Caledonia and the New Hebrides). In the New Hebrides, direct colonial competition with France signified that Australians often focused on the legal, religious and commercial conflicts between French and British citizens. The perceived French threat to Australians diminished after World War I, as did French interest in the territories. This indicated that French ambitions in the Pacific gradually yielded to indifference in the first half of the twentieth century, just as Australians assumed a more active and international interest in the region.

In contrast to Australian, German, French and British rule, the Japanese colonial system in the Pacific was heavily bureaucratic and authoritarian. ${ }^{91}$ And yet, the development of Japanese literature regarding Nanyo (the South Seas) shared many similarities with Australian writing. Japan's official entry into the Pacific was dominated by its occupation of Micronesia during the interwar period-from when it was awarded all of Micronesia (except Guam) as a Class C mandated territory after World War I until the Pacific War in 1941. Japan produced a prolific number of writings about the Pacific during this time, as well as before the interwar

90 Matt Matsuda, Empire of Love: Histories of France and the Pacific (New York: Oxford University Press, 2005), 7.

91 Lal and Fortune, The Pacific Islands, 236-37; Mark R Peattie, Nan'yo: The Rise and Fall of the Japanese in Micronesia, 1885-1945 (Honolulu: University of Hawai'i Press, 1988), 104. 
period, of which several scholars have written about. ${ }^{92}$ The broad trends in Japanese literature share similarities with Australian themes: they began with fictional, romantic stereotypes of the tropics and savagery due to European-American influences in the late 1800s (nanshin ron), which were then followed by the development of Japan's own distinct and nationalistic prose that advocated expansion into the Pacific (shosetsu), which was then subsequently followed by a more empathetic shift in the interwar period that corresponded to the opening of shipping lanes and tourism. ${ }^{93}$ Both Australia and Japan were relatively new nations and were keen to distinguish themselves from the 'old world', with their authors affirming the racial relationships between their nations and their colonial subjects (though the Japanese used ethnography in support of anti-Western sentiment to justify Japanese claims to the region). ${ }^{94}$ Ryota Nishino's research on Japanese travel writers in the Pacific has revealed that, like Australians, Japanese travel writers were also keenly aware of their audience and publishers, and they frequently had ambiguous responses to meeting Pacific Islanders face to face. ${ }^{95}$

Although Japan and Australia were both relatively new nations on the international scene, they rarely identified with one another. Conversely, the US was an emerging colonial power in the Pacific that Australians respected and sometimes even imitated. Scholars have thoroughly addressed the subject of the US's literary imaginations of the Islands, often in reference to American imperialism in the North Pacific and the

92 See Peattie, Nan'yo; David L Hanlon, Upon a Stone Altar: A History of the Island of Pohnpei to 1890 (Honolulu: University of Hawai'i Press, 1988), doi.org/10.2307/j.ctvp2n4g9; Francis X Hezel, Strangers in Their Own Land: A Century of Colonial Rule in the Caroline and Marshall Islands (Honolulu: University of Hawai'i Press, 1995); Faye Yuan Kleeman, Under an Imperial Sun: Japanese Colonial Literature of Taiwan and the South (Honolulu: University of Hawai' $\mathrm{i}$ Press, 2003); Naoto Sudo, Nanyo-Orientalism: Japanese Representations of the Pacific (New York: Cambria Press, 2010); Michele M Mason and Helen JS Yee, Reading Colonial Japan: Text, Context, Critique (Stanford: Stanford University Press, 2012); Mark Alan Ombrello, 'Monstrous Projections and Paradisal Visions: Japanese Conceptualizations of the South Seas (nan'yō) as a Supernatural Space from Ancient Times to the Contemporary Period' (PhD thesis, University of Hawai' $\mathrm{i}, 2014$ ); Robert Thomas Tierney, Tropics of Savagery: The Culture of Japanese Empire in Comparative Frame (Berkeley: University of California Press, 2010), doi.org/10.1525/california/9780520265783.001.0001.

93 Sudo, Nanyo-Orientalism, 5, 8.

94 Sudo, Nanyo-Orientalism, 5; Peattie, Nanyo, 91-5.

95 Ryota Nishino, 'Tales of Two Fijis: Early 1960s Japanese Travel Writing by Kanetaka Kaoru and Kita Morio', Journal of Pacific History 49, no. 4 (2014): 440-56, doi.org/10.1080/00223344.2014. 974300; Nishino, 'The Self-Promotion of a Maverick Travel Writer', 1-13. 
Caribbean. ${ }^{96}$ Australians were influenced by American literature, and their work found popularity with American readers. This literary relationship preceded Australia's official diplomatic shift away from Britain and closer to the US after World War II. American and Australian perspectives of the Pacific shared many similarities. Both nations were keen to distinguish themselves from European colonial powers, and both considered the Pacific a space in which to enact their own imperial ambitions. Australians referred to this as a 'new imperialism', while Americans relied on the concepts of a 'Manifest Destiny' and 'America's Pacific Lake'. Although the US had already engaged in imperialism in other parts of the world, William Davis attested that the US's involvement in the Pacific was perceived to have been conducted in a discrete period that marked the country's transition into an empire. ${ }^{97}$

Like Australia, the US's initial engagement in the Pacific region was marked by commercial ventures, and the travel writing that was produced reflected this accordingly. Rob Wilson argued that:

Authors of national cultures (such as Melville, Twain, Henry Adams, Michener, P.F. Kluge, and Theroux) in prolific works of prose possessed these 'Happy Isles of Oceania' as innocent isolatos of their own democratic-commercial empire. ${ }^{98}$

Americans were actively engaged in whaling, trade and plantation activities in the Pacific, with Hawai'i quickly becoming a global port of call. It was a frequent destination for Australian and American travellers. Although Hawai' $\mathrm{i}$ was notable among Australians for its hybridised cultures (both Asian and American) and its modern tourist developments, it was

96 For example, see William Davis, 'Pioneering the Pacific: Imagining Polynesia in United States Literature from 1820 to 1940 ' (PhD thesis, The Claremont Graduate University, 2002); Jeffrey Geiger, Facing the Pacific: Polynesia and the U.S. Imperial Imagination (Honolulu: University of Hawai'i Press, 2007); Paul Lyons, 'Pacific Scholarship, Literary Criticism, and Touristic Desire: The Specter of A. Grove Day', Boundary 24, no. 2 (1997): 47-78, doi.org/10.2307/303763; Paul Lyons, American Pacificism: Oceania in the U.S. Imagination (New York: Routledge, 2006); Christopher McBride, The Colonizer Abroad: Island Representations in American Prose from Herman Melville to Jack London (New York: Routledge, 2004), doi.org/10.4324/9780203494400; Rob Wilson, Reimagining the American Pacific: From South Pacific to Bamboo Ridge and Beyond (Durham: Duke University Press, 2000), doi.org/10.1215/9780822380979; Peter Hulme, 'The Silent Language of the Face: The Perception of Indigenous Difference in Travel Writing About the Caribbean', in Perspectives on Travel Writing, ed. Glenn Hooper and Tim Youngs (London: Routledge, 2004), 85-98; Christine Skwiot, The Purposes of Paradise: U.S. Tourism and Empire in Cuba and Hawai $i$ (Philadelphia: University of Pennsylvania Press, 2010), doi.org/10.9783/9780812200034.

97 Davis, 'Pioneering the Pacific'.

98 Wilson, Reimagining the American Pacific, 65. 
represented in numerous ways in US literature-including as a luxurious and exotic holiday destination, as a hill from which the US radiated the benefits of civilisation to the Pacific, or as the ideal melting pot from which to model the nation. ${ }^{99}$ Australia's own relationship with its colonial acquisitions in the Pacific was markedly different from the US in this respect.

Both US and Australian travel writing used the Pacific as a space for ideological and cultural debate, as well as a place in which the forbidden could be explored. This was crucial for the development of a national culture and identity in both nations. In some cases, American writers were opposed to the US's imperialist expansion in the Pacific. ${ }^{100}$ Australian attitudes to American colonialism were much less critical, especially since the American empire was largely confined to the North Pacific-a region that Australians rarely visited (except for Hawai $i$ ). Australians were instead more concerned about the islands closer to home and focused their colonial critiques on the British empire, with who they were most familiar. This distinguished Australian travel writers from their American counterparts for most of the early twentieth century.

Ultimately, Australian travellers were willing to adapt and incorporate different notions, themes and styles into their accounts; as such, a clearly defined Australian character is difficult to discern in the broad corpus of travel writing. The records that Australian travellers left behind highlight a more complex understanding of what it meant to be an 'Australian' in the late nineteenth and early twentieth centuries—an understanding that was influenced by notions of race, gender and class. Australia's position on the periphery allowed travellers to test the boundaries of what was acceptable in European society, and the Pacific Islands were the closest region in which this experiment could be engaged. These records thus illuminate how notions about the new Australian nation were formed in response to global encounters and interactions.

Shrouded in myth and mystery, the South Seas were an attractive notion in Australian and European imaginings, persisting throughout the nineteenth and early twentieth centuries. Australia's early maritime connections to the Pacific have often been overlooked in favour of a nationalist history

99 See Christine Skwiot, 'Itineraries of Empire: The Uses of US Tourism in Cuba and Hawai' $i$, 1898-1959' (PhD thesis, The State University of New Jersey, 2005); Skwiot, The Purposes of Paradise. 100 Geiger, Facing the Pacific, 13. 
that focused on the continent rather than on the connections that spread outwards from it. Travel writing offers glimpses into how Australia was connected to the broader region and how the South Seas were a part of other regional and national spheres of influence. The political boundaries that divided islands and cultures could be as temporary and fluid as the travellers themselves; as such, travellers preferred more generalised terms to imagine the geographical region. Similarly, Australians were as diverse as the peoples that they encountered-and whether they considered themselves Australian, Britisher, colonial or Australasian, the experience of travel served only to magnify the ambiguities and uncertainties of identity. Some travellers returned confident and proud to be distinctively Australian citizens, while others could be unsettled from their initial convictions. This process of self-questioning began as soon as these travellers stepped onto the boat. 
This text is taken from Australian Travellers in the South Seas, by Nicholas Halter, published 2021 by ANU Press, The Australian National University, Canberra, Australia.

doi.org/10.22459/ATSS.2021.01 